\title{
СИНТЕЗ ОПТИМАЛЬНИХ КОМБІНАТОРНИХ ПЛАНІВ БАГАТОФАКТОРНОГО ЕКСПЕРИМЕНТУ
}

\section{Рецензент - доктор технічних наук М. Д. Кошовий}

\begin{abstract}
Проблема побудови оптимального плану може бути вирішена за допомогою як комп'ютерних програм, так $і$ довідників-каталогів з типовими ріменнями. Для ичього доиільно розробляти системи автоматизачії науково-технічних експериментів, які дадуть змогу скоротити терміни проведення експериментальних досліджень $i$ зменшити витрати на них, звільнити експериментатора від рутинних операцій $і$ виконати складні експерименти. Запропоновано композиційний метод побудови планів багатофакторних експериментів, близьких до оптимальних для значної кількості факторів (10 і більше), в основі якого лежить багаторівнева композиція локальних оптимальних планів БФЕ. Розглянуто рішення поетапних завдань методу, наведені приклади побудови планів БФЕ за допомогою локальних оптимальних планів БФЕ. Застосування запропонованого методу дасть змогу спростити прочес побудови близьких до оптимальних планів БФЕ для великої кількості факторів.
\end{abstract}

Ключові слова: обчислювальні методи, математичне моделювання, експериментальні дослідження, оптимізація, планування експериментів.

Постановка проблеми. У технологічних дослідженнях для багатьох задач, наприклад, пошук багатокомпонентних матеріалів, розробка одержання їх рецептур, найвигідніших характеристик систем, оптимальної конструкції приладів та ін., характерна велика кількість факторів, рівні яких можна інтерпретувати як множину дискретних елементів. Найбільш ефективним у цьому випадку $\epsilon$ застосування комбінаторних методів під час побудови планів експерименту. Задачу побудови оптимальних за вартісними або часовими витратами планів експерименту можна вирішувати як за допомогою електронних обчислювальних машин, так і за допомогою довідників-каталогів 3 типовими рішеннями. Застосування комбінаторних планів дає змогу значно скоротити перебір варіантів, істотно зменшити витрати машинного часу. Досі відсутній загальний підхід до побудови оптимальних за вартісними і часовими витратами комбінаторних планів експерименту, тому наукова проблема розвитку теорії комбінаторних планів вимагає створен- ня нових методів та підходів для побудови і дослідження нових математичних об'єктів.

Аналіз останніх досліджень і публікацій, у яких започатковано розв'язання проблеми. Уніфікація і типізація планів експерименту перспективний напрямок. Під уніфікацією розуміють раціональне скорочення типів виробів або процесів однакового функціонального призначення, а під типізацією - розробку типових рішень, в яких відображаються загальні для низки процесів елементи або характеристики [6].

Під час класифікації планів експерименту розглядалися різні підходи, засновані на видах моделей, характеристиках планів та іншому. Перші довідники-каталоги факторних планів були розроблені в національному бюро стандартів США $[15,16]$, але вони можуть бути застосовані для окремих випадків і для невеликої кількості факторів. Каталоги планів, розроблені В. З. Бродським [12], Т. І. Голіковою [1], Р. Ф. Мержановою [9], охоплюють більшість 3 використовуваних на практиці планів для моделей, лінійних за параметрами, які найбільш часто зустрічаються в практичних дослідженнях. Водночас розглядалися плани експерименту 3 моделями головних ефектів і моделями 3 двухфакторною взаємодією дворівневих кількісних факторів. Максимальна кількість дослідів - 64, максимальна кількість факторів - 40, максимальна кількість рівнів - 8 . Автором запропоновані методи опису планів експерименту і способи їх побудови. Показано, що задача знаходження оптимального виду перетворення плану зводиться до задачі цілочисельного лінійного програмування.

Каталоги планів другого порядку розглянуті в роботах $[2,3]$. Аналіз статистичних характеристик планів третього порядку показали, що для оцінки коефіцієнтів кубічних регресій використовуються плани наступних типів: повної кубічної моделі, моделі головних ефектів, моделі без кубів змінних, моделі без квадратів і кубів, моделі лінійні за однією змінною і кубічні за другою та інші.

Під час дослідження комбінаторних планів, що враховують вартість зміни рівнів факторів у 


\section{TEХНIЧНI НАУКИ}

процесі експерименту, розглянутих в роботах [7, 4], визначено, що істотними є наступні види перетворень: СP (column permutation), LP (line permutation), CN (column negation), LN (line negation). Запропоновано SP класифікація планів структур планів експерименту. Для побудови системи різних представників планів БФЕ пропонується інваріантний підхід [11].

Результатом уніфікації і типізації є побудова каталогів типових планів БФЕ, що володіють певними властивостями. Для визначення кількості типових варіантів і побудови множини типових представників використовується теорія перерахування комбінаторного аналізу, яка займається знаходженням і дослідженням формул для точного і асимптотичного підрахунку елементів у різних класах комбінаторних об'єктів. Рішення конкретного завдання перерахування дає змогу встановити специфічні комбінаторні властивості вихідних об'єктів, які проявляються в самій процедурі обчислення або випливають 3 отриманих результатів $[10,13]$.

У даний час використовуються наступні методи перерахування: метод безпосередніх підрахунків, метод рекуррентних співвідношень, метод похідних функцій, асимптотичні методи, теорія обчислення Пойа. Метод похідних функцій, висвітлений в роботах П. Дубіль, Дж. К. Рота, Р. Стенлі [5], має розвинений математичний апарат та зводить обчислювальні комбінаторні завдання до визначення числа послідовностей, що володіють, або що не володіють деякими спеціальними властивостями. У комбінаторному аналізі застосовуються функції різного виду: степенні ряди, функції експоненціального типу, ряди Діріхле, Ейлєрові функції та інше.

У випадку подання планів МФЕ в даний час традиційно використовуються таблиці [17]. Каталоги планів МФЕ, побудовані у вигляді таблиць, наведені в роботах [14]. Недоліком табличного способу подання є складність роботи з таблицями великих розмірів. Наприклад, плани повного БФЕ $3 \mathrm{n}$ факторами мають розмір $2^{\mathrm{n}} \times \mathrm{n}$. Спосіб компактного представлення планів МФЕ запропонований Марковою в роботі [8], але істотних переваг він не дає. Під час пошуку оптимальних комбінаторних планів МФЕ, що враховують вартість зміни рівнів факторів, істотним $\epsilon$ порядок виконання дослідів. Перетворення таблиць для цього завдання досить трудомісткий

$$
\begin{gathered}
\Pi\left(X_{1}, \ldots, X_{i-1}, X_{i}, X_{i+1}, \ldots, X_{k}\right) / X_{i}= \\
=\Pi\left(X_{1}, \ldots, X_{i-1},-1, X_{i+1}, \ldots, X_{k}\right) \cup \Pi\left(X_{1}, \ldots, X_{i-1},+1, X_{i+1}, \ldots, X_{k}\right)= \\
=X_{i}^{-1} \Pi_{1}\left(X_{1}, \ldots, X_{i-1}, X_{i+1}, \ldots, X_{k}\right) \cup X_{i}^{+1} \Pi_{2}\left(X_{1}, \ldots, X_{i-1}, X_{i+1}, \ldots, X_{k}\right) .
\end{gathered}
$$

процес. Серед відомих методів візуалізації та способів графічної ілюстрації слід зазначити діаграми Венна, які показують математичні, теоретико-множинні або логічні взаємозв'язки між множинами і подіями. На жаль, ці способи представлення планів не враховують специфіку комбінаторних планів БФЕ.

Отже, відомі методи обчислення орієнтовані переважно на окремі види об'єктів, рішення задач - занадто трудомісткі, а одержані формули громіздкі. Тому перспективним напрямом $\epsilon$ уніфікація і типізація планів експерименту, в основі яких лежить класифікація планів експерименту.

Метою дослідження $є$ модифікація та розвиток теорії математичного моделювання реальних явищ, об'єктів, систем та процесів як сукупності формалізованих дій (операцій) для складання ефективних математичних описів об'єктів, що досліджуються.

Завданням дослідження є розробка теоретичних основ та практична реалізація формального представлення планів багатофакторного експерименту у вигляді діаграм спеціального виду, основаних на використанні карт Карно, що дає змогу наглядно відображати процеси перетворення таких планів та їх властивостей.

Методи дослідження. Для розв'язання поставленої проблеми були використані основні положення зазначених теорій: комбінаторного аналізу, планування експерименту, символьних послідовностей, множин, моделювання, математичної статистики, оптимізації, програмування. Водночас для оптимізації планів експерименту за часовими i вартісними витратами застосовуються комбінаторні методи, теорія символьних послідовностей, теорія множин, такі методи оптимізації, як повний перебір, метод послідовного наближення.

Результати дослідження. Для побудови комбінаторних планів, близьких до оптимального (тому що повний перебір вже у випадку 16 дослідів практично є неможливим), розроблено метод синтезу комбінаторних LP-планів. В основі методу лежать операції з планами експериментів: декомпозиція та композиція планів. Розглянемо їх.

Декомпозицією плану експерименту П $\left(\mathrm{X}_{1}, \ldots\right.$, $\mathrm{X}_{\mathrm{i}-1}, \mathrm{X}_{\mathrm{i}}, \mathrm{X}_{\mathrm{i}+1}, \ldots, \mathrm{X}_{\mathrm{k}}$ ) за фактором $\mathrm{X}_{\mathrm{i}}$ називається подання плану експерименту таким чином: 
Плани експерименту, які формуються у результаті виділення дослідів 3 певним фіксованим значенням факторів, що використовуються у декомпозиції, будемо називати частковими планами експерименту.
Приклад процесу декомпозиції початкового плану експерименту $\Pi\left(X_{1}, X_{2}, X_{3}, X_{4}, X_{5}\right)$ (табл. 1) за фактором $X_{1}$ наведено у табл. 2 . У табл. 3 і 4 наведено часткові плани експерименту $\Pi_{1}\left(X_{2}, X_{3}\right.$, $\left.X_{4}, X_{5}\right)$ i $\Pi_{2}\left(X_{2}, X_{3}, X_{4}, X_{5}\right)$.

\section{1. Початковий план експерименту}

\begin{tabular}{|c|c|c|c|c|c|c|c|c|c|c|c|c|c|c|c|c|c|c|}
\hline $\begin{array}{c}\text { Номер } \\
\text { досліду }\end{array}$ & $\mathrm{X}_{1}$ & $\mathrm{X}_{2}$ & $\mathrm{X}_{3}$ & $\mathrm{X}_{4}$ & $\mathrm{X}_{5}$ & $\begin{array}{c}\text { Номер } \\
\text { досліду }\end{array}$ & $\mathrm{X}_{1}$ & $\mathrm{X}_{2}$ & $\mathrm{X}_{3}$ & $\mathrm{X}_{4}$ & $\mathrm{X}_{5}$ & $\begin{array}{c}\text { Номер } \\
\text { досліду }\end{array}$ & $\mathrm{X}_{1}$ & $\mathrm{X}_{2}$ & $\mathrm{X}_{3}$ & $\mathrm{X}_{4}$ & $\mathrm{X}_{5}$ \\
\hline 1 & +1 & +1 & -1 & -1 & +1 & 12 & +1 & +1 & +1 & +1 & -1 & 23 & -1 & +1 & +1 & -1 & +1 \\
\hline 2 & -1 & -1 & +1 & -1 & -1 & 13 & +1 & -1 & +1 & -1 & +1 & 24 & -1 & +1 & +1 & +1 & +1 \\
\hline 3 & +1 & +1 & -1 & -1 & -1 & 14 & -1 & -1 & +1 & +1 & +1 & 25 & +1 & -1 & +1 & -1 & +1 \\
\hline 4 & +1 & -1 & -1 & +1 & -1 & 15 & +1 & -1 & -1 & -1 & +1 & 26 & -1 & -1 & -1 & +1 & +1 \\
\hline 5 & +1 & +1 & +1 & -1 & +1 & 16 & -1 & -1 & -1 & -1 & -1 & 27 & +1 & -1 & +1 & +1 & -1 \\
\hline 6 & -1 & +1 & +1 & +1 & +1 & 17 & -1 & -1 & -1 & +1 & -1 & 28 & +1 & -1 & +1 & +1 & +1 \\
\hline 7 & -1 & +1 & -1 & +1 & -1 & 18 & +1 & -1 & +1 & -1 & -1 & 29 & -1 & -1 & -1 & -1 & -1 \\
\hline 8 & +1 & -1 & -1 & +1 & +1 & 19 & -1 & -1 & -1 & -1 & +1 & 30 & -1 & +1 & +1 & +1 & -1 \\
\hline 9 & -1 & -1 & +1 & +1 & -1 & 20 & +1 & +1 & -1 & +1 & +1 & 31 & -1 & +1 & -1 & -1 & -1 \\
\hline 10 & +1 & +1 & +1 & -1 & -1 & 21 & +1 & +1 & -1 & +1 & -1 & 32 & -1 & +1 & -1 & -1 & +1 \\
\hline 11 & -1 & +1 & -1 & +1 & +1 & 22 & +1 & +1 & +1 & -1 & -1 & & & & & & \\
\hline
\end{tabular}

\section{2. Перетворений план експерименту}

\begin{tabular}{|c|c|c|c|c|c|c|c|c|c|c|c|c|c|c|c|c|c|c|c|}
\hline$X_{1}$ & $X_{2}$ & $X_{3}$ & $X_{4}$ & $X_{5}$ & $X_{1}$ & $X_{2}$ & $X_{3}$ & $X_{4}$ & $\mathrm{X}_{5}$ & $X_{1}$ & $X_{2}$ & $X_{3}$ & $X_{4}$ & $X_{5}$ & $\mathrm{X}_{1}$ & $X_{2}$ & $X_{3}$ & $X_{4}$ & $X_{5}$ \\
\hline \multirow{8}{*}{-1} & -1 & +1 & -1 & -1 & \multirow{8}{*}{-1} & -1 & -1 & -1 & +1 & \multirow{7}{*}{+1} & +1 & -1 & -1 & +1 & \multirow{7}{*}{+1} & +1 & +1 & -1 & -1 \\
\hline & +1 & +1 & +1 & +1 & & +1 & +1 & -1 & +1 & & +1 & -1 & -1 & -1 & & +1 & +1 & -1 & -1 \\
\hline & +1 & -1 & +1 & -1 & & +1 & +1 & +1 & +1 & & -1 & -1 & +1 & -1 & & +1 & +1 & +1 & -1 \\
\hline & -1 & +1 & +1 & -1 & & -1 & -1 & +1 & +1 & & +1 & +1 & -1 & +1 & & -1 & +1 & -1 & +1 \\
\hline & +1 & -1 & +1 & +1 & & -1 & -1 & -1 & -1 & & -1 & -1 & +1 & +1 & & -1 & -1 & -1 & +1 \\
\hline & -1 & +1 & +1 & +1 & & +1 & +1 & +1 & -1 & & -1 & +1 & -1 & -1 & & -1 & +1 & -1 & +1 \\
\hline & -1 & -1 & -1 & -1 & & +1 & -1 & -1 & -1 & & +1 & -1 & +1 & +1 & & -1 & +1 & +1 & -1 \\
\hline & -1 & -1 & +1 & -1 & & +1 & -1 & -1 & +1 & & +1 & -1 & +1 & -1 & & -1 & +1 & +1 & +1 \\
\hline
\end{tabular}

\section{3. Частковий план експерименту $\Pi_{1}\left(X_{2}, X_{3}, X_{4}, X_{5}\right)$}

\begin{tabular}{|c|c|c|c|c|c|c|c|c|c|c|c|c|c|c|c|}
\hline $\mathrm{X}_{2}$ & $\mathrm{X}_{3}$ & $\mathrm{X}_{4}$ & $\mathrm{X}_{5}$ & $\mathrm{X}_{2}$ & $\mathrm{X}_{3}$ & $\mathrm{X}_{4}$ & $\mathrm{X}_{5}$ & $\mathrm{X}_{2}$ & $\mathrm{X}_{3}$ & $\mathrm{X}_{4}$ & $\mathrm{X}_{5}$ & $\mathrm{X}_{2}$ & $\mathrm{X}_{3}$ & $\mathrm{X}_{4}$ & $\mathrm{X}_{5}$ \\
\hline-1 & +1 & -1 & -1 & +1 & -1 & +1 & +1 & -1 & -1 & -1 & +1 & -1 & -1 & -1 & -1 \\
\hline+1 & +1 & +1 & +1 & -1 & +1 & +1 & +1 & +1 & +1 & -1 & +1 & +1 & +1 & +1 & -1 \\
\hline+1 & -1 & +1 & -1 & -1 & -1 & -1 & -1 & +1 & +1 & +1 & +1 & +1 & -1 & -1 & -1 \\
\hline-1 & +1 & +1 & -1 & -1 & -1 & +1 & -1 & -1 & -1 & +1 & +1 & +1 & -1 & -1 & +1 \\
\hline
\end{tabular}

4. Частковий план експерименту $\Pi_{2}\left(X_{2}, X_{3}, X_{4}, X_{5}\right)$

\begin{tabular}{|c|c|c|c||c|c|c|c|c|c|c|c|c|c|c|c|}
\hline $\mathrm{X}_{2}$ & $\mathrm{X}_{3}$ & $\mathrm{X}_{4}$ & $\mathrm{X}_{5}$ & $\mathrm{X}_{2}$ & $\mathrm{X}_{3}$ & $\mathrm{X}_{4}$ & $\mathrm{X}_{5}$ & $\mathrm{X}_{2}$ & $\mathrm{X}_{3}$ & $\mathrm{X}_{4}$ & $\mathrm{X}_{5}$ & $\mathrm{X}_{2}$ & $\mathrm{X}_{3}$ & $\mathrm{X}_{4}$ & $\mathrm{X}_{5}$ \\
\hline+1 & -1 & -1 & +1 & -1 & -1 & +1 & +1 & +1 & +1 & -1 & -1 & -1 & -1 & -1 & +1 \\
\hline+1 & -1 & -1 & -1 & -1 & +1 & -1 & -1 & +1 & +1 & -1 & -1 & -1 & +1 & -1 & +1 \\
\hline-1 & -1 & +1 & -1 & +1 & -1 & +1 & +1 & +1 & +1 & +1 & -1 & -1 & +1 & +1 & -1 \\
\hline+1 & +1 & -1 & +1 & +1 & -1 & +1 & -1 & -1 & +1 & -1 & +1 & -1 & +1 & +1 & +1 \\
\hline
\end{tabular}

Аналогічно визначається декомпозиція за двома й більше факторами:

$\Pi\left(X_{1}, \ldots, X_{i-1}, X_{i}, X_{i+1}, \ldots, X_{j-1}, X_{j}, X_{j+1}, \ldots, X_{k}\right) / X_{i} X_{j}=$

$=\Pi\left(X_{1}, \ldots, X_{i-1},-1, X_{i+1}, \ldots, X_{j-1},-1, X_{j+1}, \ldots, X_{k}\right) \cup \Pi\left(X_{1}, \ldots, X_{i-1},-1, X_{i+1}, \ldots,+1, X_{j}, X_{j+1}, \ldots, X_{k}\right) \cup \Pi\left(X_{1}\right.$, $\left.\ldots, X_{i-1},+1, X_{i+1}, \ldots, X_{j-1},-1, X_{j+1}, \ldots, X_{k}\right) \cup \Pi\left(X_{1}, \ldots, X_{i-1},+1, X_{i+1}, \ldots, X_{j-1},+1, X_{j+1}, \ldots, X_{k}\right)=X_{i}^{-1} X_{j}^{-1} \Pi_{1}\left(X_{1}\right.$, $\left.\ldots, X_{i-1}, X_{i+1}, \ldots, X_{j-1}, X_{j+1}, \ldots, X_{k}\right) \cup X_{i}^{-1} X_{j}^{+1} \Pi_{2}\left(X_{1}, \ldots, X_{i-1}, X_{i+1}, \ldots, X_{j}, X_{j+1}, \ldots, X_{k}\right) \cup X_{i}^{+1} X_{j}^{-1} \Pi_{3}\left(X_{1}, \ldots, X_{i-1}\right.$, $\left.X_{i+1}, \ldots, X_{j-1}, X_{j+1}, \ldots, X_{k}\right) \cup X_{i}^{+1} X_{j}^{+1} \Pi_{4}\left(X_{1}, \ldots, X_{i-1}, X_{i+1}, \ldots, X_{j-1}, X_{j+1}, \ldots, X_{k}\right)$. 
Перетворений план експерименту й часткові плани за факторами $\mathrm{X}_{1}$ i $\mathrm{X}_{2}$, отримані в результаті декомпозиції плану експерименту $\Pi\left(X_{1}, X_{2}\right.$, $X_{3}, X_{4}, X_{5}$ ) (табл. 1$)$, наведено в табл. 5-9.

Наведений процес декомпозиції можна подати у вигляді табл. 10. У загальному випадку процес декомпозиції можна навести у вигляді поетапного розподілу початкового плану експерименту на часткові плани (рис. 1).

\section{5. Перетворений за факторами $X_{1}$ i $X_{2}$ вихідний план експерименту}

\begin{tabular}{|c|c|c|c|c|c|c|c|c|c|c|c|c|c|c|c|c|c|c|c|}
\hline $\mathrm{X}_{1}$ & $\mathrm{X}_{2}$ & $\mathrm{X}_{3}$ & $\mathrm{X}_{4}$ & $\mathrm{X}_{5}$ & $\mathrm{X}_{1}$ & $\mathrm{X}_{2}$ & $\mathrm{X}_{3}$ & $\mathrm{X}_{4}$ & $\mathrm{X}_{5}$ & $\mathrm{X}_{1}$ & $\mathrm{X}_{2}$ & $\mathrm{X}_{3}$ & $\mathrm{X}_{4}$ & $\mathrm{X}_{5}$ & $\mathrm{X}_{1}$ & $\mathrm{X}_{2}$ & $\mathrm{X}_{3}$ & $\mathrm{X}_{4}$ & $\mathrm{X}_{5}$ \\
\hline \multirow{8}{*}{-1} & \multirow{8}{*}{-1} & +1 & -1 & -1 & \multirow{8}{*}{+1} & \multirow{8}{*}{-1} & -1 & +1 & -1 & \multirow{8}{*}{-1} & \multirow{8}{*}{+1} & +1 & +1 & +1 & \multirow{8}{*}{+1} & \multirow{8}{*}{+1} & +1 & -1 & +1 \\
\hline & & +1 & +1 & -1 & & & -1 & +1 & +1 & & & -1 & +1 & -1 & & & -1 & -1 & +1 \\
\hline & & +1 & +1 & +1 & & & +1 & -1 & -1 & & & -1 & +1 & +1 & & & -1 & -1 & -1 \\
\hline & & -1 & -1 & -1 & & & +1 & -1 & +1 & & & +1 & -1 & +1 & & & -1 & +1 & +1 \\
\hline & & -1 & +1 & -1 & & & -1 & -1 & +1 & & & +1 & +1 & +1 & & & -1 & +1 & -1 \\
\hline & & -1 & -1 & +1 & & & +1 & -1 & +1 & & & +1 & +1 & -1 & & & +1 & -1 & -1 \\
\hline & & -1 & +1 & +1 & & & +1 & +1 & -1 & & & -1 & -1 & -1 & & & +1 & -1 & -1 \\
\hline & & -1 & -1 & -1 & & & +1 & +1 & +1 & & & -1 & -1 & +1 & & & +1 & +1 & -1 \\
\hline
\end{tabular}

\section{6. Частковий план експерименту}

\begin{tabular}{|c|c|c|c|c|c|}
\multicolumn{7}{c}{$\Pi_{1}\left(\mathrm{X}_{3}, \mathrm{X}_{4}, \mathrm{X}_{5}\right)$} \\
\hline $\mathrm{X}_{3}$ & $\mathrm{X}_{4}$ & $\mathrm{X}_{5}$ & $\mathrm{X}_{3}$ & $\mathrm{X}_{4}$ & $\mathrm{X}_{5}$ \\
\hline+1 & -1 & -1 & -1 & +1 & -1 \\
\hline+1 & +1 & -1 & -1 & -1 & +1 \\
\hline+1 & +1 & +1 & -1 & +1 & +1 \\
\hline-1 & -1 & -1 & -1 & -1 & -1 \\
\hline
\end{tabular}

8. Частковий план експерименту

\begin{tabular}{|c|c|c|c|c|c|}
\multicolumn{7}{c}{$\Pi_{3}\left(\mathrm{X}_{3}, \mathrm{X}_{4}, \mathrm{X}_{5}\right)$} \\
\hline $\mathrm{X}_{3}$ & $\mathrm{X}_{4}$ & $\mathrm{X}_{5}$ & $\mathrm{X}_{3}$ & $\mathrm{X}_{4}$ & $\mathrm{X}_{5}$ \\
\hline-1 & +1 & -1 & -1 & -1 & +1 \\
\hline-1 & +1 & +1 & +1 & -1 & +1 \\
\hline+1 & -1 & -1 & +1 & +1 & -1 \\
\hline+1 & -1 & +1 & +1 & +1 & +1 \\
\hline
\end{tabular}

\section{7. Частковий план експерименту}

\begin{tabular}{|c|c|c|c|c|c|}
\multicolumn{7}{c|}{$\Pi_{2}\left(\mathrm{X}_{3}, \mathrm{X}_{4}, \mathrm{X}_{5}\right)$} \\
\hline $\mathrm{X}_{3}$ & $\mathrm{X}_{4}$ & $\mathrm{X}_{5}$ & $\mathrm{X}_{3}$ & $\mathrm{X}_{4}$ & $\mathrm{X}_{5}$ \\
\hline+1 & +1 & +1 & +1 & +1 & +1 \\
\hline-1 & +1 & -1 & +1 & +1 & -1 \\
\hline-1 & +1 & +1 & -1 & -1 & -1 \\
\hline+1 & -1 & +1 & -1 & -1 & +1 \\
\hline
\end{tabular}

\section{9. Частковий план експерименту}

\begin{tabular}{|c|c|c|c|c|c|}
\multicolumn{7}{c}{$\Pi_{4}\left(\mathrm{X}_{3}, \mathrm{X}_{4}, \mathrm{X}_{5}\right)$} \\
\hline $\mathrm{X}_{3}$ & $\mathrm{X}_{4}$ & $\mathrm{X}_{5}$ & $\mathrm{X}_{3}$ & $\mathrm{X}_{4}$ & $\mathrm{X}_{5}$ \\
\hline+1 & -1 & +1 & -1 & +1 & -1 \\
\hline-1 & -1 & +1 & +1 & -1 & -1 \\
\hline-1 & -1 & -1 & +1 & -1 & -1 \\
\hline-1 & +1 & +1 & +1 & +1 & -1 \\
\hline
\end{tabular}

\section{0. Подання вихідного плану експерименту}

\begin{tabular}{|c|c|c|}
\hline \multicolumn{2}{|c|}{$\begin{array}{c}\text { Кодовані значення факторів, } \\
\text { застосовані у декомпозиції }\end{array}$} & $\begin{array}{c}\text { Часткові плани експерименту, реалізовані залежно } \\
\text { від значень факторів } \mathrm{X}_{1} \text { i } \mathrm{X}_{2}\end{array}$ \\
\cline { 1 - 2 } $\mathrm{X}_{1}$ & $\mathrm{X}_{2}$ & $\Pi_{1}\left(\mathrm{X}_{3}, \mathrm{X}_{4}, \mathrm{X}_{5}\right)$ \\
\hline-1 & -1 & $\Pi_{2}\left(\mathrm{X}_{3}, \mathrm{X}_{4}, \mathrm{X}_{5}\right)$ \\
\hline-1 & +1 & $\Pi_{3}\left(\mathrm{X}_{3}, \mathrm{X}_{4}, \mathrm{X}_{5}\right)$ \\
\hline+1 & -1 & $\Pi_{4}\left(\mathrm{X}_{3}, \mathrm{X}_{4}, \mathrm{X}_{5}\right)$ \\
\hline+1 & +1 & \\
\hline
\end{tabular}

Задача побудови плану експерименту із заданими властивостями залежить від особливостей часткових планів. Для планів експериментів, на множині яких діють операції LP-перетворень, пропонується використовувати метод композиції, що $є$ зворотним відносно задачі декомпозиції планів і має деякі особливості. Для побудови комбінаторних LP-планів експерименту пропонується використовувати як часткові оптимальні комбінаторні LP-плани за кількості дослідів $\mathrm{n} \leq 8$ $(\mathrm{k} \leq 3)$, які наведено в таблиці 11. 


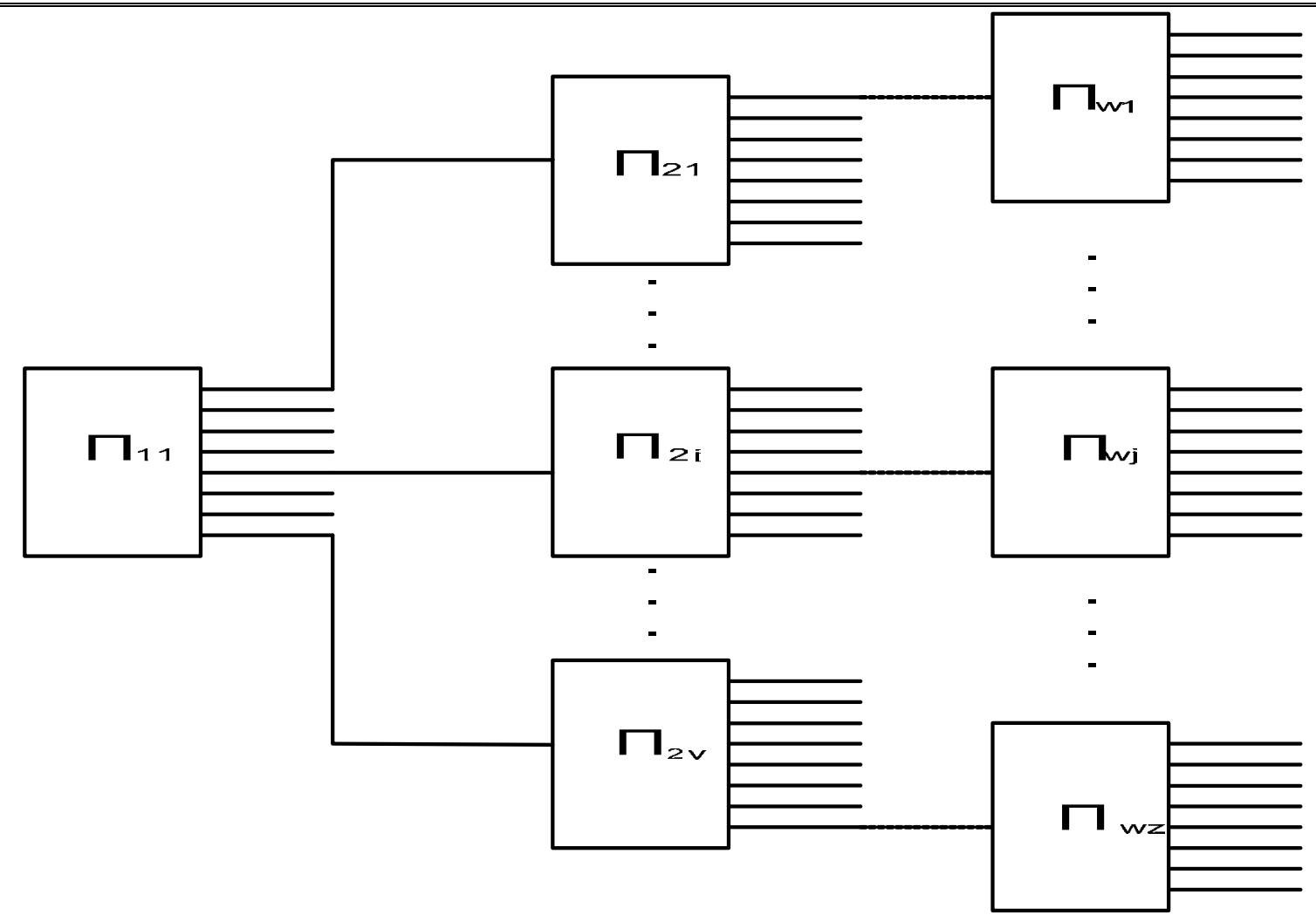

Рис. 1. Подання процесу декомпозицї плану експерименту в загальному вигляді

Основні етапи методу синтезу комбінаторних LP-планів:

Eтап 1. Розглядається множина факторів $\mathrm{X}^{0}=$ $\left\{\mathrm{X}_{1}^{0}, \mathrm{X}_{2}^{0}, \ldots, \mathrm{X}_{\mathrm{k}}^{0}\right\}$ і визначається середня вартість зміни їхніх рівнів $\mathrm{S}^{0}=\left\{\mathrm{S}_{1}{ }^{0}, \mathrm{~S}_{2}{ }^{0}, \ldots, \mathrm{S}_{\mathrm{k}}{ }^{0}\right\}$.

Етап 2. Впорядковуються фактори за убуванням середньої вартості. У результаті одержується впорядкована множина факторів.

$\mathrm{X}=\left\{\mathrm{X}_{1}, \mathrm{X}_{2}, \ldots, \mathrm{X}_{\mathrm{k}}\right\}$ з визначенням вартості зміни рівнів $\mathrm{S}=\left\{\mathrm{S}_{1}, \mathrm{~S}_{2}, \ldots, \mathrm{S}_{\mathrm{k}}\right\}$.

Етап 3. Розбивається множина факторів $X=$ $\left\{\mathrm{X}_{1}, \mathrm{X}_{2}, \ldots, \mathrm{X}_{\mathrm{k}}\right\}$ справа наліво на групи з трьох факторів. Кількість факторів в останній групі може бути від одного до трьох.

Етап 4. Будується структура плану експерименту. Для цього визначається кількість планів у кожній групі. Позначається кількість груп через $\mathrm{t}$, а кількість планів у кожній групі $\mathrm{Q}=\left\{\mathrm{q}_{1}, \mathrm{q}_{2}, \ldots\right.$, $\left.\mathrm{q}_{\mathrm{t}}\right)$, де $\mathrm{q}_{1} \in\{1,2,3\}, \mathrm{q}_{\mathrm{i}}=3, \mathrm{i}=2, \ldots, \mathrm{t}$. На першому рівні існує тільки один план, у якому кількість дослідів $\mathrm{E}_{1}=2^{\mathrm{q} 1}$. Кожному досліду першого рівня відповідають $\mathrm{E}_{1}$ планів другого рівня. Всі плани другого й наступних рівнів мають вісім дослідів. Тоді кількість дослідів другого рівня $\mathrm{E}_{2}$ $=\mathrm{E}_{1} \cdot 8$. Аналогічно для третього рівня $\mathrm{E}_{3}=\mathrm{E}_{2} \cdot 8 \mathrm{i}$ Т.П.

Етап 5. Визначається оптимальний вид часткового плану експерименту в кожній групі за допомогою розробленого програмного забезпечення залежно від вартості зміни рівнів факторів. Для зменшення сумарної вартості зміни рівнів факторів для планів, що входять у відповідну групу, необхідно, щоб кодування рівнів факторів у восьмому досліді і-го плану й першому досліді $(\mathrm{i}+1)$-го плану було однаковим. У цьому випадку перехід від плану до плану в межах однієї групи дорівнює нулю.

На рис. 2 зображено процес композиції LPпланів експерименту. Стрілками показано переходи між планами однієї групи.

Комбінаторний план експерименту, як приклад для застосування описаного методу, наведено в табл. 12, а вартості зміни рівнів факторів - у табл. 13. 
TЕХНІЧНI НАУКИ

\section{1. Каталог оптимальних типових варіантів планів БФЕ, $n=8$}

\begin{tabular}{|c|c|c|c|c|c|c|c|c|c|c|c|c|c|c|c|c|c|}
\hline № п/П & \multicolumn{8}{|c|}{ План } & № п/П & \multicolumn{8}{|c|}{ План } \\
\hline 1 & 1 & 5 & 6 & 2 & 4 & 3 & 7 & 8 & 42 & 5 & 7 & 3 & 1 & 2 & 4 & 8 & 6 \\
\hline 2 & 5 & 6 & 2 & 1 & 3 & 7 & 8 & 4 & 43 & 1 & 5 & 7 & 3 & 4 & 8 & 6 & 2 \\
\hline 3 & 1 & 2 & 6 & 5 & 7 & 8 & 4 & 3 & 44 & 5 & 7 & 3 & 4 & 8 & 6 & 2 & 1 \\
\hline 4 & 2 & 6 & 5 & 7 & 8 & 4 & 3 & 1 & 45 & 5 & 7 & 8 & 4 & 3 & 1 & 2 & 6 \\
\hline 5 & 6 & 2 & 1 & 5 & 7 & 8 & 4 & 3 & 46 & 5 & 1 & 3 & 7 & 8 & 4 & 2 & 6 \\
\hline 6 & 6 & 5 & 7 & 8 & 4 & 2 & 1 & 3 & 47 & 3 & 1 & 5 & 7 & 8 & 4 & 2 & 6 \\
\hline 7 & 6 & 5 & 7 & 8 & 4 & 3 & 1 & 2 & 48 & 3 & 1 & 5 & 7 & 8 & 6 & 2 & 4 \\
\hline 8 & 6 & 5 & 1 & 3 & 7 & 8 & 4 & 2 & 49 & 5 & 1 & 3 & 7 & 8 & 6 & 2 & 4 \\
\hline 9 & 2 & 6 & 5 & 1 & 3 & 7 & 8 & 4 & 50 & 5 & 7 & 8 & 6 & 2 & 1 & 3 & 4 \\
\hline 10 & 3 & 1 & 2 & 6 & 5 & 7 & 8 & 4 & 51 & 5 & 7 & 8 & 6 & 2 & 4 & 3 & 1 \\
\hline 11 & 6 & 5 & 7 & 3 & 1 & 2 & 4 & 8 & 52 & 1 & 5 & 7 & 8 & 6 & 2 & 4 & 3 \\
\hline 12 & 6 & 2 & 1 & 5 & 7 & 3 & 4 & 8 & 53 & 7 & 5 & 1 & 3 & 4 & 8 & 6 & 2 \\
\hline 13 & 1 & 2 & 6 & 5 & 7 & 3 & 4 & 8 & 54 & 3 & 7 & 5 & 1 & 2 & 4 & 8 & 6 \\
\hline 14 & 6 & 5 & 1 & 2 & 4 & 3 & 7 & 8 & 55 & 3 & 7 & 8 & 4 & 2 & 1 & 5 & 6 \\
\hline 15 & 6 & 2 & 4 & 3 & 1 & 5 & 7 & 8 & 56 & 7 & 8 & 4 & 3 & 1 & 5 & 6 & 2 \\
\hline 16 & 4 & 2 & 6 & 5 & 1 & 3 & 7 & 8 & 57 & 7 & 8 & 6 & 5 & 1 & 2 & 4 & 3 \\
\hline 17 & 4 & 3 & 1 & 2 & 6 & 5 & 7 & 8 & 58 & 7 & 8 & 6 & 5 & 1 & 3 & 4 & 2 \\
\hline 18 & 1 & 3 & 4 & 2 & 6 & 5 & 7 & 8 & 59 & 3 & 7 & 8 & 6 & 5 & 1 & 2 & 4 \\
\hline 19 & 4 & 3 & 7 & 5 & 1 & 2 & 6 & 8 & 60 & 7 & 8 & 6 & 2 & 4 & 3 & 1 & 5 \\
\hline 20 & 4 & 2 & 1 & 3 & 7 & 5 & 6 & 8 & 61 & 7 & 8 & 4 & 2 & 6 & 5 & 1 & 3 \\
\hline 21 & 1 & 2 & 4 & 3 & 7 & 5 & 6 & 8 & 62 & 7 & 8 & 4 & 3 & 1 & 2 & 6 & 5 \\
\hline 22 & 7 & 3 & 4 & 2 & 1 & 5 & 6 & 8 & 63 & 3 & 7 & 8 & 4 & 2 & 6 & 5 & 1 \\
\hline 23 & 7 & 5 & 1 & 3 & 4 & 2 & 6 & 8 & 64 & 1 & 3 & 7 & 8 & 4 & 2 & 6 & 5 \\
\hline 24 & 7 & 5 & 6 & 2 & 1 & 3 & 4 & 8 & 65 & 7 & 3 & 4 & 8 & 6 & 5 & 1 & 2 \\
\hline 25 & 7 & 3 & 1 & 5 & 6 & 2 & 4 & 8 & 66 & 7 & 3 & 4 & 8 & 6 & 2 & 1 & 5 \\
\hline 26 & 1 & 3 & 7 & 5 & 6 & 2 & 4 & 8 & 67 & 7 & 3 & 1 & 2 & 4 & 8 & 6 & 5 \\
\hline 27 & 2 & 1 & 3 & 7 & 5 & 6 & 8 & 4 & 68 & 1 & 2 & 4 & 3 & 7 & 8 & 6 & 5 \\
\hline 28 & 3 & 7 & 5 & 1 & 2 & 6 & 8 & 4 & 69 & 2 & 4 & 3 & 7 & 8 & 6 & 5 & 1 \\
\hline 29 & 1 & 3 & 7 & 5 & 6 & 8 & 4 & 2 & 70 & 4 & 2 & 1 & 3 & 7 & 8 & 6 & 5 \\
\hline 30 & 3 & 7 & 5 & 6 & 8 & 4 & 2 & 1 & 71 & 4 & 3 & 7 & 8 & 6 & 2 & 1 & 5 \\
\hline 31 & 7 & 3 & 1 & 5 & 6 & 8 & 4 & 2 & 72 & 4 & 3 & 7 & 8 & 6 & 5 & 1 & 2 \\
\hline 32 & 7 & 5 & 6 & 8 & 4 & 3 & 1 & 2 & 73 & 4 & 8 & 7 & 3 & 1 & 2 & 6 & 5 \\
\hline 33 & 7 & 5 & 6 & 8 & 4 & 2 & 1 & 3 & 74 & 8 & 7 & 3 & 4 & 2 & 6 & 5 & 1 \\
\hline 34 & 7 & 5 & 1 & 2 & 6 & 8 & 4 & 3 & 75 & 8 & 7 & 5 & 6 & 2 & 4 & 3 & 1 \\
\hline 35 & 5 & 7 & 3 & 1 & 2 & 6 & 8 & 4 & 76 & 8 & 7 & 5 & 6 & 2 & 1 & 3 & 4 \\
\hline 36 & 1 & 5 & 7 & 3 & 4 & 2 & 6 & 8 & 77 & 8 & 7 & 3 & 1 & 5 & 6 & 2 & 4 \\
\hline 37 & 3 & 4 & 2 & 1 & 5 & 7 & 8 & 6 & 78 & 8 & 7 & 5 & 1 & 3 & 4 & 2 & 6 \\
\hline 38 & 4 & 3 & 1 & 5 & 7 & 8 & 6 & 2 & 79 & 8 & 7 & 3 & 4 & 2 & 1 & 5 & 6 \\
\hline 39 & 2 & 4 & 3 & 1 & 5 & 7 & 8 & 6 & 80 & 8 & 4 & 2 & 1 & 3 & 7 & 5 & 6 \\
\hline 40 & 5 & 1 & 2 & 4 & 3 & 7 & 8 & 6 & 81 & 8 & 4 & 3 & 7 & 5 & 1 & 2 & 6 \\
\hline 41 & 2 & 1 & 5 & 7 & 3 & 4 & 8 & 6 & 82 & 8 & 4 & 3 & 7 & 5 & 6 & 2 & 1 \\
\hline
\end{tabular}


Продовження таблииі 11

\begin{tabular}{|c|c|c|c|c|c|c|c|c||c|c|c|c|c|c|c|c|c|c|}
\hline № П/П & \multicolumn{10}{|c|}{ План П/П } & \multicolumn{1}{|c|}{ План } \\
\hline 83 & 4 & 8 & 7 & 5 & 6 & 2 & 1 & 3 & 114 & 6 & 2 & 4 & 8 & 7 & 5 & 1 & 3 \\
\hline 84 & 2 & 4 & 8 & 7 & 3 & 1 & 5 & 6 & 115 & 6 & 2 & 4 & 8 & 7 & 3 & 1 & 5 \\
\hline 85 & 4 & 8 & 7 & 3 & 1 & 5 & 6 & 2 & 116 & 6 & 2 & 1 & 3 & 4 & 8 & 7 & 5 \\
\hline 86 & 3 & 4 & 8 & 7 & 5 & 6 & 2 & 1 & 117 & 6 & 8 & 4 & 3 & 7 & 5 & 1 & 2 \\
\hline 87 & 1 & 3 & 4 & 8 & 7 & 5 & 6 & 2 & 118 & 6 & 8 & 4 & 2 & 1 & 3 & 7 & 5 \\
\hline 88 & 3 & 4 & 8 & 7 & 5 & 1 & 2 & 6 & 119 & 2 & 6 & 8 & 4 & 3 & 7 & 5 & 1 \\
\hline 89 & 3 & 1 & 2 & 4 & 8 & 7 & 5 & 6 & 120 & 1 & 2 & 6 & 8 & 4 & 3 & 7 & 5 \\
\hline 90 & 2 & 1 & 3 & 4 & 8 & 7 & 5 & 6 & 121 & 6 & 8 & 7 & 3 & 4 & 2 & 1 & 5 \\
\hline 91 & 2 & 1 & 3 & 4 & 8 & 6 & 5 & 7 & 122 & 2 & 6 & 8 & 7 & 5 & 1 & 3 & 4 \\
\hline 92 & 3 & 1 & 2 & 4 & 8 & 6 & 5 & 7 & 123 & 6 & 8 & 7 & 5 & 1 & 3 & 4 & 2 \\
\hline 93 & 3 & 4 & 8 & 6 & 2 & 1 & 5 & 7 & 124 & 6 & 8 & 7 & 5 & 1 & 2 & 4 & 3 \\
\hline 94 & 2 & 4 & 8 & 6 & 5 & 1 & 3 & 7 & 125 & 6 & 8 & 4 & 2 & 1 & 5 & 7 & 3 \\
\hline 95 & 4 & 8 & 6 & 5 & 7 & 3 & 1 & 2 & 126 & 2 & 6 & 8 & 4 & 3 & 1 & 5 & 7 \\
\hline 96 & 4 & 8 & 6 & 2 & 1 & 5 & 7 & 3 & 127 & 2 & 6 & 5 & 1 & 3 & 4 & 8 & 7 \\
\hline 97 & 2 & 4 & 8 & 6 & 5 & 7 & 3 & 1 & 128 & 6 & 5 & 1 & 2 & 4 & 8 & 7 & 3 \\
\hline 98 & 1 & 2 & 4 & 8 & 6 & 5 & 7 & 3 & 129 & 5 & 6 & 8 & 7 & 3 & 4 & 2 & 1 \\
\hline 99 & 8 & 4 & 2 & 6 & 5 & 7 & 3 & 1 & 130 & 1 & 5 & 6 & 8 & 7 & 3 & 4 & 2 \\
\hline 100 & 8 & 4 & 2 & 6 & 5 & 1 & 3 & 7 & 131 & 5 & 6 & 8 & 7 & 3 & 1 & 2 & 4 \\
\hline 101 & 8 & 4 & 3 & 1 & 2 & 6 & 5 & 7 & 132 & 5 & 1 & 2 & 6 & 8 & 7 & 3 & 4 \\
\hline 102 & 8 & 6 & 2 & 4 & 3 & 1 & 5 & 7 & 133 & 2 & 1 & 5 & 6 & 8 & 7 & 3 & 4 \\
\hline 103 & 8 & 6 & 5 & 1 & 2 & 4 & 3 & 7 & 134 & 2 & 1 & 5 & 6 & 8 & 4 & 3 & 7 \\
\hline 104 & 8 & 6 & 2 & 1 & 5 & 7 & 3 & 4 & 135 & 5 & 1 & 2 & 6 & 8 & 4 & 3 & 7 \\
\hline 105 & 8 & 6 & 5 & 7 & 3 & 1 & 2 & 4 & 136 & 5 & 6 & 8 & 4 & 2 & 1 & 3 & 7 \\
\hline 106 & 8 & 6 & 5 & 7 & 3 & 4 & 2 & 1 & 137 & 1 & 5 & 6 & 2 & 4 & 8 & 7 & 3 \\
\hline 107 & 8 & 6 & 2 & 4 & 3 & 7 & 5 & 1 & 138 & 5 & 6 & 2 & 4 & 8 & 7 & 3 & 1 \\
\hline 108 & 4 & 8 & 6 & 2 & 1 & 3 & 7 & 5 & 139 & 5 & 6 & 2 & 1 & 3 & 4 & 8 & 7 \\
\hline 109 & 1 & 3 & 4 & 2 & 6 & 8 & 7 & 5 & 140 & 3 & 1 & 5 & 6 & 2 & 4 & 8 & 7 \\
\hline 110 & 3 & 4 & 2 & 6 & 8 & 7 & 5 & 1 & 141 & 5 & 1 & 3 & 4 & 2 & 6 & 8 & 7 \\
\hline 111 & 4 & 3 & 1 & 2 & 6 & 8 & 7 & 5 & 142 & 4 & 2 & 1 & 5 & 6 & 8 & 7 & 3 \\
\hline 112 & 4 & 2 & 6 & 8 & 7 & 3 & 1 & 5 & 143 & 2 & 4 & 3 & 1 & 5 & 6 & 8 & 7 \\
\hline 113 & 4 & 2 & 6 & 8 & 7 & 5 & 1 & 3 & 144 & 3 & 4 & 2 & 1 & 5 & 6 & 8 & 7 \\
\hline
\end{tabular}
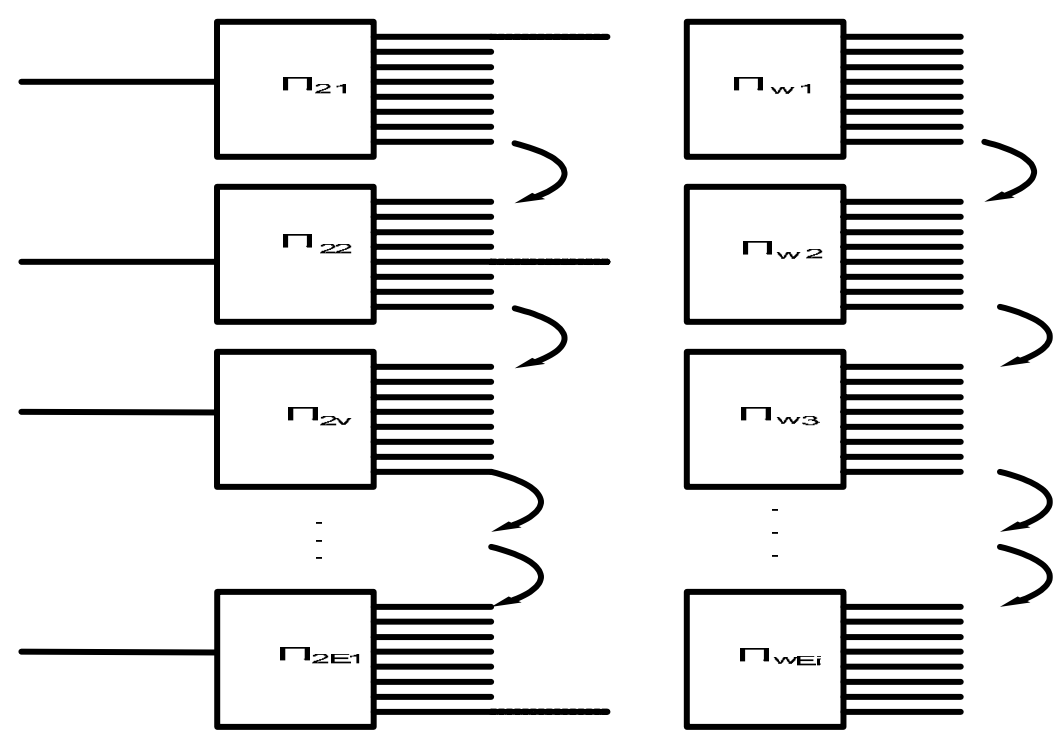

Рис. 2. Процес композицї LP-планів експерименту 


\section{2. Початковий план експерименту}

\begin{tabular}{|c|c|c|c|c|c|c|c|c|c|}
\hline \multirow{2}{*}{$\begin{array}{l}\text { Номер } \\
\text { досліду }\end{array}$} & \multicolumn{4}{|c|}{ Кодовані значення факторів } & \multirow{2}{*}{$\begin{array}{l}\text { Номер } \\
\text { досліду }\end{array}$} & \multicolumn{4}{|c|}{ Кодовані значення факторів } \\
\hline & $\mathrm{X}_{1}$ & $\mathrm{X}_{2}$ & $\mathrm{X}_{3}$ & $\mathrm{X}_{4}$ & & $\mathrm{X}_{1}$ & $\mathrm{X}_{2}$ & $\mathrm{X}_{3}$ & $\mathrm{X}_{4}$ \\
\hline 1 & +1 & +1 & -1 & +1 & 9 & +1 & -1 & -1 & +1 \\
\hline 2 & +1 & +1 & +1 & +1 & 10 & +1 & -1 & +1 & +1 \\
\hline 3 & +1 & -1 & +1 & -1 & 11 & +1 & +1 & +1 & -1 \\
\hline 4 & -1 & -1 & +1 & +1 & 12 & -1 & +1 & -1 & +1 \\
\hline 5 & -1 & +1 & +1 & -1 & 13 & -1 & +1 & +1 & +1 \\
\hline 6 & -1 & +1 & -1 & -1 & 14 & -1 & -1 & -1 & +1 \\
\hline 7 & +1 & +1 & -1 & -1 & 15 & -1 & -1 & -1 & -1 \\
\hline 8 & +1 & -1 & -1 & -1 & 16 & -1 & -1 & +1 & -1 \\
\hline
\end{tabular}

\section{3. Вартості змін значень факторів}

\begin{tabular}{|c|c|c|c|c|c|}
\hline Позначення & \multicolumn{2}{|c|}{ Вартість зміни, ум. од. } & Позначення & \multicolumn{2}{|c|}{ Вартість зміни, ум. од. } \\
факторів & від «-1» до «+1» & від «+1» до «-1» & факторів & від «-1» до «+1» & від «+1» до «-1» \\
\hline $\mathrm{X}_{1}$ & 18,85 & 7,45 & $\mathrm{X}_{3}$ & 0,18 & 0,18 \\
\hline $\mathrm{X}_{2}$ & 8,65 & 4,45 & $\mathrm{X}_{4}$ & 1,15 & 0,77 \\
\hline
\end{tabular}

\section{4. План експерименту $\Pi_{1}\left(X_{2}, X_{4}, X_{3}\right)$}

\begin{tabular}{|c|c|c|c|c|c|c|c|c|c|c|c|c|c|c|c|c|c|c|c|c|c|c|c|}
\hline $\mathrm{X}_{2}$ & $\mathrm{X}_{4}$ & $\mathrm{X}_{3}$ & $\mathrm{X}_{2}$ & $\mathrm{X}_{4}$ & $\mathrm{X}_{3}$ & $\mathrm{X}_{2}$ & $\mathrm{X}_{4}$ & $\mathrm{X}_{3}$ & $\mathrm{X}_{2}$ & $\mathrm{X}_{4}$ & $\mathrm{X}_{3}$ & $\mathrm{X}_{2}$ & $\mathrm{X}_{4}$ & $\mathrm{X}_{3}$ & $\mathrm{X}_{2}$ & $\mathrm{X}_{4}$ & $\mathrm{X}_{3}$ & $\mathrm{X}_{2}$ & $\mathrm{X}_{4}$ & $\mathrm{X}_{3}$ & $\mathrm{X}_{2}$ & $\mathrm{X}_{4}$ & $\mathrm{X}_{3}$ \\
\hline+1 & +1 & -1 & +1 & -1 & -1 & +1 & -1 & +1 & +1 & +1 & +1 & -1 & +1 & +1 & -1 & -1 & +1 & -1 & -1 & -1 & -1 & +1 & -1 \\
\hline
\end{tabular}

1. Розглядаємо множину факторів $\mathrm{X}^{0}=\left\{\mathrm{X}_{1}^{0}\right.$, $\left.\mathrm{X}_{2}{ }^{0}, \ldots, \mathrm{X}_{4}{ }^{0}\right\}$ і визначаємо середню вартість зміни їхніх рівнів $\mathrm{S}^{0}=\left\{\mathrm{S}_{1}{ }^{0}, \mathrm{~S}_{2}{ }^{0}, \ldots, \mathrm{S}_{4}{ }^{0}\right\}$ :

$\mathrm{S}_{1}{ }^{0}=(18,85+7,45) / 2=13,15$;

$\mathrm{S}_{2}{ }^{0}=(8,65+4,45) / 2=6,55$;

$\mathrm{S}_{3}{ }^{0}=(0,18+0,18) / 2=0,18$

$\mathrm{S}_{4}{ }^{0}=(1,15+0,77) / 2=0,96$.

2. Впорядковуємо фактори щодо зменшення середньої вартості. У результаті одержуємо впорядковану множину факторів $X=\left\{X_{1}, X_{2}, \ldots, X_{4}\right\}$ із вартостями зміни рівнів $S=\left\{S_{1}, S_{2}, \ldots, S_{4}\right\}: X=$ $\left\{X_{1}, X_{2}, X_{4}, X_{3}\right\}, S=\{13,15,6,55,0,96,0,18\}$.

3. Розбиваємо множину факторів на групи по три фактори. У першій групі тільки один фактор $-X_{1}$, а в другій $-X_{2}, X_{4}, X_{3}$.

4. Будуємо структуру плану експерименту. Оскільки вартість зміни рівнів першого фактора $\mathrm{S}^{01}>\mathrm{S}^{10}$, то план експерименту має структуру:

$\Pi\left(X_{1}, X_{2}, X_{3}, X_{4}\right)=X_{i}^{+1} \Pi_{1}\left(X_{2}, X_{4}, X_{3}\right) \cup$ $X_{i}^{-1} \Pi_{2}\left(X_{2}, X_{4}, X_{3}\right)$.
5. Визначаємо за допомогою розробленого програмного забезпечення оптимальний план експерименту $\Pi_{1}\left(\mathrm{X}_{2}, \mathrm{X}_{4}, \mathrm{X}_{3}\right)$ (табл. 14).

Під час побудови другого часткового плану експерименту слід враховувати, що для зменшення вартості переходів між планами $\Pi_{1}\left(\mathrm{X}_{2}, \mathrm{X}_{4}\right.$, $\left.\mathrm{X}_{3}\right)$ і $\Pi_{2}\left(\mathrm{X}_{2}, \mathrm{X}_{4}, \mathrm{X}_{3}\right)$ необхідно, щоб план $\Pi_{2}\left(\mathrm{X}_{2}\right.$, $\mathrm{X}_{4}, \mathrm{X}_{3}$ ) починався 3 досліду, що збігається 3 останнім дослідом плану $\Pi_{1}\left(\mathrm{X}_{2}, \mathrm{X}_{4}, \mathrm{X}_{3}\right)$, тобто:

\begin{tabular}{|c|c|c|}
\hline $\mathrm{X}_{2}$ & $\mathrm{X}_{4}$ & $\mathrm{X}_{3}$ \\
\hline-1 & +1 & -1 \\
\hline
\end{tabular}

Визначаємо за допомогою розробленого програмного забезпечення оптимальний план експерименту $\Pi_{2}\left(\mathrm{X}_{2}, \mathrm{X}_{4}, \mathrm{X}_{3}\right)$ (табл. 15$)$.

6. Виконуємо композицію плану експерименту $\Pi\left(X_{1}, X_{2}, X_{3}, X_{4}\right)=X_{i}^{+1} \Pi_{1}\left(X_{2}, X_{4}, X_{3}\right) \cup$ $\mathrm{X}_{\mathrm{i}}^{-1} \Pi_{2}\left(\mathrm{X}_{2}, \mathrm{X}_{4}, \mathrm{X}_{3}\right)$. У результаті одержуємо план експерименту, наведений у табл. 16.

\section{5. План експерименту $\Pi_{2}\left(X_{2}, X_{4}, X_{3}\right)$}

\begin{tabular}{|c|c|c|c|c|c|c|c|c|c|c|c|c|c|c|c|c|c|c|c|c|c|c|c|}
\hline $\mathrm{X}_{2}$ & $\mathrm{X}_{4}$ & $\mathrm{X}_{3}$ & $\mathrm{X}_{2}$ & $\mathrm{X}_{4}$ & $\mathrm{X}_{3}$ & $\mathrm{X}_{2}$ & $\mathrm{X}_{4}$ & $\mathrm{X}_{3}$ & $\mathrm{X}_{2}$ & $\mathrm{X}_{4}$ & $\mathrm{X}_{3}$ & $\mathrm{X}_{2}$ & $\mathrm{X}_{4}$ & $\mathrm{X}_{3}$ & $\mathrm{X}_{2}$ & $\mathrm{X}_{4}$ & $\mathrm{X}_{3}$ & $\mathrm{X}_{2}$ & $\mathrm{X}_{4}$ & $\mathrm{X}_{3}$ & $\mathrm{X}_{2}$ & $\mathrm{X}_{4}$ & $\mathrm{X}_{3}$ \\
\hline-1 & +1 & -1 & -1 & -1 & -1 & -1 & -1 & +1 & -1 & +1 & +1 & +1 & +1 & +1 & +1 & -1 & +1 & +1 & -1 & -1 & +1 & +1 & -1 \\
\hline
\end{tabular}


16. План експерименту, отриманий у результаті композиції

\begin{tabular}{|c|c|c|c|c|c|c|c|c|c|}
\hline $\begin{array}{c}\text { Номер } \\
\text { досліду }\end{array}$ & $\mathrm{X}_{1}$ & $\mathrm{X}_{2}$ & $\mathrm{X}_{3}$ & $\mathrm{X}_{4}$ & $\begin{array}{c}\text { Номер } \\
\text { досліду }\end{array}$ & $\mathrm{X}_{1}$ & $\mathrm{X}_{2}$ & $\mathrm{X}_{3}$ & $\mathrm{X}_{4}$ \\
\hline 1 & +1 & +1 & +1 & -1 & 9 & -1 & -1 & +1 & -1 \\
\hline 2 & +1 & +1 & -1 & -1 & 10 & -1 & -1 & -1 & -1 \\
\hline 3 & +1 & +1 & -1 & +1 & 11 & -1 & -1 & -1 & +1 \\
\hline 4 & +1 & +1 & +1 & +1 & 12 & -1 & -1 & +1 & +1 \\
\hline 5 & +1 & -1 & +1 & +1 & 13 & -1 & +1 & +1 & +1 \\
\hline 6 & +1 & -1 & -1 & +1 & 14 & -1 & +1 & -1 & +1 \\
\hline 7 & +1 & -1 & -1 & -1 & 15 & -1 & +1 & -1 & -1 \\
\hline 8 & +1 & -1 & +1 & -1 & 16 & -1 & +1 & +1 & -1 \\
\hline
\end{tabular}

Висновок. Сучасний метод планування експерименту призначений розширити технологію промислового планування експерименту і складається 3 інтегрованих методів і засобів планування, виконання та аналізу експерименту.

Для наочності перетворень і відбиття властивостей планів БФЕ пропонується представляти їх у вигляді діаграм спеціального виду, які відображують порядок виконання дослідів і відповідні

\section{БІБЛІОГРАФІЯ}

1. Голикова Т. И. Каталог планов второго порядка [текст] / Т. И. Голикова, Л. А. Панченко, М. 3. Фридман. - М. : изд-во МГУ, 1974. - 224 с.

2. Голикова Т. И. Некоторые выводы по каталогу планов второго порядка [текст] / Т. И. Голикова, Л. А. Панченко, М. 3. Фридман // Тезисы IV Всесоюзной конференции по планированию эксперимента. - М. : Наука, 1973. - Ч.1. - С. 23-26.

3. Голикова Т. И. Систематизация планов второго порядка [текст] / Т. И. Голикова, Л. А. Панченко // Планирование оптимальных экспериментов. - М. : изд-во МГУ, 1975. - С. 106-149.

4. Диаграммы комбинаторных планов многофакторного эксперимента [текст] / [Цеховской М. В., Кошевой Н. Д., Костенко Е. М., Павлик А. В., Кныш В. А.] // Науково-технічний журнал «Радіоелектронні і комп’ютерні системи». - №1 (53). - X. : XAI, 2012. - C. 110-113.

5. Дубиле П. Об основах комбинаторной теории. Идея производящей функции [текст] / П. Дубиле, Дж. Рота, Р. Стенли // Перечислительные задачи комбинаторного анализа. - М. : Мир, 1979. - С. 260-281.

6. Колчков В. И. Метрология, стандартизация и сертификация [Электронный ресурс]. - 2011. Режим доступа : http://micromake.ru/old/msisbook/ msisstand $1 \mathrm{c} . \mathrm{htm}$.

7. Кочевой Н. Д. Классификация планов многофакторного эксперимента [текст] / Н. Д. Кошевой, А. В. Павлик, В. П. Сироклын // Збірник значення рівнів факторів, що використовується за композиції і декомпозиції планів БФЕ; водночас вказуються фактори, які беруть участь у перетворенні плану БФЕ, та вид часткового плану, що реалізується.

Отриманий за допомогою описаного методу план має вартість зміни рівнів факторів в 2,79 рази менше, ніж початковий план експерименту.

наукових праць Харківського університету повітряних сил. - 2008. - Вып. 1 (16). - С. 65-67.

8. Маркова E. В. Комбинаторные планы в задачах многофакторного эксперимента [текст] / Е. В. Маркова, А. Н. Лисенков. - М. : Наука, 1979. - 347 c.

9. Мержанова Р. Ф. Каталог планов третьего порядка [текст] / Р. Ф. Мержанова, Е. П. Никитина. - М. : изд-во МГУ, 1979. - 169 с.

10. Перечислительные задачи комбинаторного анализа [текст] // Сб. переводов под ред Г. П. Гаврилова. - М. : Мир, 1979. - 364 с.

11. Применение инвариантов в комбинаторных исследованиях [текст] / [Кошевой Н. Д., Павлик А. В., Сироклын В. П., Дидык Н. А.] // Збірник наукових праць військового інституту Київського національного університету ім. Т. Г. Шевченка. - 2008. - Вып. 14. - С. 83-87.

12. Таблицы планов эксперимента для факторных и полиномиальных моделей [текст] / [Бродский В. 3., Бродский Л. И., Голикова Т. И., Никитина Е. П.]. - М. : Металлургия, 1982. - 750 с.

13. Bender E. A. Enumerative uses of generating functions [техт] / E. A. Bender, J. R. Goldman // Indiana Univ. Math. J. - 1971. - V. 2. - №8. - P. 753765.

14. Goos P. Optimal Design of Experiments [техт] / P. Goos, J. Bradley. - New York : John Wiley \& Sons, 2011. -287 p.

15. Connor $W$. Fractorial factorial design for 


\section{TEХНIЧНI НАУКИ}

experiments with factor of two and three levels [техт] / W. Connor, M. Zelen // National Bureau of standards, App.

16. Fractional factorial experiment design for factor at two levels [text] // National Bureau of
Standards. App. Math. Ser. $-1962 .-85$ p.

17. $W u$ C. F. Experiments: Planning, Analysis, and Optimization [техт] / C. F. Wu, M. S. Hamada. New York : John Wiley \& Sons, 2009. - 716 p. 